\title{
Chitin synthase localization in the diatom Thalassiosira pseudonana
}

\author{
Martin Wustmann ${ }^{1}$, Nicole Poulsen², Nils Kröger ${ }^{2,3,4}$ and Karl-Heinz van Pée ${ }^{1 *}$
}

\begin{abstract}
Chitin constitutes an abundant component in many biologically formed minerals (biominerals). While the role of chitin for the formation and properties of calcium-based biominerals has been extensively studied, little is known about its role in silica-based biominerals. Furthermore, there is hardly any information about the enzyme machinery for chitin biosynthesis in biomineral-forming organisms. Here we have identified a chitin synthase, chs7305, in the diatom Thalassiosira pseudonana. In stationary cells, chs7305 is located specifically in a ring pattern in the region of the silicified girdle bands. The expression pattern of the chs7305 gene and the co-localization of the encoded enzyme with chitin provides evidence for the importance of chitin synthesis for cell wall function under nutrient limited conditions. Chs7305 is the first chitin synthase that has been localized in a diatom.
\end{abstract}

Keywords: Chitin, Chitin synthase, Thalassiosira pseudonana, Peptide antibody, Immunolocalization

\section{Introduction}

Diatoms are outstanding examples of unicellular organisms capable of forming complex shaped cell walls made of silica [1,2]. The silica building blocks of the cell wall are produced in a yet little understood morphogenetic process that is believed to involve long chain polyamines (LCPA), unique families of proteins (e.g., silaffins, silacidins), and insoluble organic matrices $[3,4]$. Three types of insoluble organic matrices were recently identified as integral components of the silica cell wall of the diatom Thalassiosira pseudonana: meshworks [5], microrings [6] and microplates [7]. The meshworks are chitinbased with proteins as minor components, whereas the microrings and microplates are mainly composed of proteins [5-7]. Many different organisms employ insoluble organic matrices as central components for the biosynthesis of mineralized structures (biomineralization) [8]. The presence of chitin is particularly well studied in $\mathrm{CaCO}_{3}$ biomineralization [8-12]. In nacre it contributes

\footnotetext{
${ }^{*}$ Correspondence: karl-heinz.vanpee@chemie.tu-dresden.de

${ }^{1}$ General Biochemistry, Technical University of Dresden, 01062 Dresden, Germany

Full list of author information is available at the end of the article
}

to high impact resistance and is believed to influence the process of biomineralization $[13,14]$. In some centric diatoms, chitin is present as crystalline $\beta$-chitin fibers that are extruded through specialized openings in the cell wall called fultoportulae. These chitin fibers are not involved in silica biomineralization, and instead are believed to slow-down the sinking rate of the photosynthetically active diatom cells by increasing their drag in the water [15-17]. Distinct from the chitin fibers are the chitin meshworks, which are tightly associated with the silica of the cell wall (rather than being extruded) suggesting a possible involvement in silica biogenesis $[5,18]$.

Potential chitin synthase genes seem to be widely distributed among diatoms and can even be found in species not known to produce extracellular chitin fibers [18]. T. pseudonana possess four potential chitin synthase genes $[18,19]$, which is consistent with the need to produce at least two different types of chitin, secreted fibers and silica-associated meshworks. Based on the amino acid sequence, it is impossible to predict which chitin synthase produces which type of chitin. To obtain information of the chitin synthases, we attempted the localization of the enzymes.

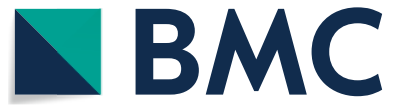

(c) The Author(s) 2020. This article is licensed under a Creative Commons Attribution 4.0 International License, which permits use, sharing, adaptation, distribution and reproduction in any medium or format, as long as you give appropriate credit to the original author(s) and the source, provide a link to the Creative Commons licence, and indicate if changes were made. The images or other third party material in this article are included in the article's Creative Commons licence, unless indicated otherwise in a credit line to the material. If material is not included in the article's Creative Commons licence and your intended use is not permitted by statutory regulation or exceeds the permitted use, you will need to obtain permission directly from the copyright holder. To view a copy of this licence, visit http://creativeco mmons.org/licenses/by/4.0/. The Creative Commons Public Domain Dedication waiver (http://creativecommons.org/publicdomain/ zero/1.0/) applies to the data made available in this article, unless otherwise stated in a credit line to the data. 
We chose to focus our studies on chitin synthase 7305 (chs7305, JGI-ID: 7305), because it is predicted to contain a myosin motor-like domain, which would indicate an intimate association of this chitin synthase with the actin cytoskeleton [18]. Actin has previously been found associated with the silica forming organelles of diatoms, the silica deposition vesicles (SDVs), and was hypothesized to influence silica biogenesis through yet unidentified transmembrane proteins in the SDV [4]. Furthermore, a chitin synthase from the mussel Mytilus galloprovincialis that also contains a predicted myosin motor domain was shown to be located in the developing shell, and was suggested to function in in the mineral biogenesis process [12].

\section{Methods}

\section{Cultivation}

T. pseudonana (CCMP1335) was grown in enriched artificial seawater medium according to the recipe of the North East Pacific Culture Collection [20] at $18^{\circ} \mathrm{C}$ under constant light (4000-7000 lx).

\section{Cloning and expression of recombinant proteins in $T$. pseudonana}

The expression of chs 7305 was done using the expression vector $\mathrm{pTpNR} /$ egfp which provides a switchable expression [21]. The chs7305 gene or gene fragments were amplified from genomic DNA with the oligonucleotides 5'-TTT GAT ATC ATG TCC TCT CGT CAC GAC GAC TC-3' and 5'-ATA GGT ACC GCT CAT GCT ACG TTT GCT CCT CG-3' (EcoRV and KpnI sites are underlined) to achieve a fusion upstream to egfp (C-terminal fusion protein). The PCR product was digested with EcoRV and $K p n \mathrm{I}$ and ligated into the vector $\mathrm{pTpNR} / E c o R V /$ KpnI/egfp. Furthermore, the oligonucleotides 5'-TTT GAT ATC ATG TCC TCT CGT CAC GAC GAC TC-3', 5'-GCT TCT GCG TCT TTC TCG TCA GGG TAC CTT T-3', 5'-TTT GCG GCC GCT TGG CTT CTT TGT GGG GAT CTT C-3' and 5'-AAA GCG GCC GCT CAG CTC ATG CTA CGT TTG CTC-3' (EcoRV, KpnI and NotI restriction sites are underlined) were used to obtain DNA fragments that split chs7305. The resulting fragments were ligated in the vector $p T p N R / E c o R V / K p n I /$ egfp/NotI to insert egfp into chs 7305 (the point of insertion locates in an extracellular domain of the corresponding protein sequence). The subsequent introduction of the expression vectors into T. pseudonana by particle bombardment and selection of recombinant cells on nourseothricin-containing agar plates was performed as described previously [21]. Successfully selected mutants were further analyzed by fluorescence microscopy and Western blotting.

\section{Peptide antibody production and specificity tests}

Peptide synthesis and subsequent immunization of rabbits was conducted by (Davids Biotechnologie (Regensburg, Germany). The peptide SEELQSTDKVCAQMTDEDKK was used as the target epitope region of chs7305. The antibody was affinity-purified by the manufacturer and the specificity was tested as follows. First, in a peptide competition assay (PCA), the synthesized peptide was pre-incubated at 10 - and 100-times excess with anti-chs 7305 for $1 \mathrm{~h}$ at $23^{\circ} \mathrm{C}$. The solution was then used for immunolocalization as described below. Second, the IgG fraction from pre-immune serum was isolated by G-Mag-Sepharose (GE Healthcare, Heidelberg, Germany) according to the manufacturer's recommendations. This IgG fraction was subsequently used for the immunolocalization at the same protein concentration as anti-chs7305.

\section{Immunofluorescence microscopy}

Cells were harvested after 10 days of growth and the immunolabelling was carried out in $50 \mathrm{mM}$ Tris-buffered saline (TBS, pH 7.5). After a single washing step, the cells were fixed in $2 \%$ formaldehyde for $2 \mathrm{~h}\left(23^{\circ} \mathrm{C}, 0.1 \%\right.$ Triton $\mathrm{X}-100)$. Subsequently, the cells were thoroughly washed and permeabilized in $1.5 \%$ Triton X-100 (1\% BSA). The pellet was again thoroughly washed followed by a blocking step with a $1 \%$ BSA solution. The incubation with the primary antibody (anti-chs7305 peptide antibody) was carried out in a 1:50 dilution overnight at $4{ }^{\circ} \mathrm{C}$. After thorough washing, anti-mouse IgG conjugated with CruzFluor488 (SantaCruz Biotechnology, Heidelberg, Germany) was applied in a 1:100 dilution. After incubation for $2 \mathrm{~h}$ at $23{ }^{\circ} \mathrm{C}$, the sample was finally washed with TBS and analyzed by epifluorescence microscopy.

Immunofluorescently labeled cells were also stained with other fluorescent dyes. Calcofluor white was used to stain chitin in labeled cells. Those were incubated in a $0.01 \%$ solution (Tris- $\mathrm{HCl}, \mathrm{pH} 8.8$ ) for $10 \mathrm{~min}$ at room temperature after immunolocalization. PDMPO (2-(4-pyridyl)-5-((4-(2-dimethylaminoethyl-aminocarbamoyl)methoxy)-phenyl)oxazole) was used to stain newly formed frustules. Therefore, PDMPO was added to the growing culture $12 \mathrm{~h}$ prior to immunolocalization at a concentration of $10 \mu \mathrm{M}$.

Epifluorescence analysis was carried out with a LSM 780 laser scanning microscope (Zeiss, Göttingen, Germany) equipped with a laser diode $(405 \mathrm{~nm})$, Ar laser $(488 \mathrm{~nm})$ and HeNe laser $(633 \mathrm{~nm})$. The detection of fluorescence signals was achieved with a photomultiplier with adjustable band width. Fluorescence images were also recorded on an Axio Observer Z1 (Zeiss, Göttingen, Germany) equipped with a metal halide UV lamp 
and the filters FS 49: EX BP 347/55; BS LP 395; EM BP 445/50 (Dapi) FS 38 HE: EX BP 470/40; BS LP 495; EM BP 525/50 (GFP) and FS 50 HE: EX BP 640/30; BS LP 660; EM BP 690/50 (Cy5) for colocalization studies with calcofluor white and anti-chs7305.

\section{Chitin staining with chitin-binding GFP (CB-GFP)}

Chitin-binding GFP is a recombinant fusion protein of the chitin-binding domain of chitinase A from Paenibacillus sp. WL-12 (former Bacillus circulans WL-12) with green-fluorescent protein that specifically binds to chitin [12]. First, the staining conditions were tested at different $\mathrm{pH}$ values to determine interactions of CB-GFP (containing a $\mathrm{His}_{6}$-tag) with silica. For this, calcined $T$. pseudonana cell walls were used. Biosilica was extracted as described previously [22] and subsequently calcined in a muffle furnace (Nabertherm) for $5 \mathrm{~h}$ at $550{ }^{\circ} \mathrm{C}$ which completely removes organic material from the cell walls [23].

The final chitin staining procedure started with an extraction with $100 \%$ methanol for $10 \mathrm{~min}$ at $23{ }^{\circ} \mathrm{C}$. This reduced the intensive fluorescence of chloroplasts. Followed by thorough washing with $50 \mathrm{mM}$ glycine- $\mathrm{NaOH}$ buffer (pH 10.0), a blocking step (1\% BSA) for $1 \mathrm{~h}$ at $23^{\circ} \mathrm{C}$ was conducted. The cell pellet was finally resuspended in an $80 \mathrm{ng} / \mu \mathrm{L}$ CB-GFP solution and incubated for $1 \mathrm{~h}$ at $23{ }^{\circ} \mathrm{C}$. After three washing steps, fluorescence microscopy analysis was carried out.

\section{Protein isolation/separation and western blotting}

T. pseudonana was grown for 10 days and the culture was harvested for protein analysis. The cell pellets were washed with $50 \mathrm{mM}$ Tris- $\mathrm{HCl}$ buffer (pH 7.0) and subsequently lysis buffer was applied (Tris- $\mathrm{HCl}, 2 \% \mathrm{SDS}$ ). After $30 \mathrm{~min}$ incubation at room temperature, the cell fragments were pelleted by centrifugation and the supernatant was kept for further analysis. Protein separation was then carried out by $10 \%$ SDS-Tris-glycinePAGE. SDS-PAGE loading buffer (8 M urea, $100 \mathrm{mM}$ Tris, $70 \mathrm{mM}$ SDS) was added to the samples and a $5 \mathrm{~min}$ incubation at $37{ }^{\circ} \mathrm{C}$ was conducted. Following electrophoresis, proteins were transferred to an Amersham polyvinylidene fluoride (PVDF) membrane (GE Healthcare, Heidelberg, Germany) by electroblotting (Bio-Rad, Trans-Blot ${ }^{\mathrm{TM}}$ Cell) and an immunostaining was carried out in $50 \mathrm{mM}$ TBS (pH 7.5). This started with an $8 \mathrm{~h}$ blocking step (5\% milk powder, $0.05 \%$ Tween20, TBST milk), followed by the addition of anti-GFP antibody conjugated with horseradish peroxidase (SantaCruz Biotechnology, Heidelberg, Germany) at 1:1000 dilution in fresh TBST milk. Finally, the membrane was thoroughly washed with TBS. The luminescence reaction was conducted with SuperSignal WestPico (ThermoScientific; Rockford, USA) and detected on an Amersham X-Ray film (GE Healthcare, Heidelberg, Germany).

\section{Results and discussion}

Initially chs7305 was expressed in T. pseudonana with the GFP gene fused to the C-terminus. However, the observed GFP localization pattern (Fig. 1a) appeared to indicate that the GFP is retarded in the endoplasmatic reticulum [26]. After gentle protein extraction to avoid membrane protein aggregation, Western blot analysis indicated that the expressed chs7305-GFP fusion protein was truncated and corresponds to the size of GFP itself $(27 \mathrm{kDa})$ and not to the full-length fusion protein (159 kDa, Fig. 1b).

The position of GFP was then switched to an extracellular domain of chs7305, which led to no fluorescence at all. Surprisingly, GFP was still detectable by Western blot analysis. However, again the size of the resulting GFP fusion protein was considerably smaller $(\sim 38 \mathrm{kDa})$ than the predicted size $(159 \mathrm{kDa})$. This result was confirmed by the investigation of at least three independent positive egfp-containing clones. The mechanism which lead to the small protein size observed after Western blotting is unclear. The reasons for the absence of GFP fluorescence and the detection of only partial fusion proteins were not investigated further and remain elusive. However, a possible cause for this might be the quenching of GFP fluorescence by acidic conditions inside a vesicle.

The small fusion protein size and the localization pattern raised concerns about the applicability of this approach for the localization of chitin synthases in $T$. pseudonana. Consequently, we decided to pursue immunolocalization. Polyclonal antibodies were raised against four synthetic peptides specific for the T. pseudonana chitin synthases: chs7305, chs6575, chs 4368 and chs 4413 . Since only the antibodies against chs7305 showed a specific signal with respect to the control experiments (see experimental section), the chitin synthase chs7305 was chosen for the final study. Immunolocalization with antichs7305 resulted in well-defined fluorescence patterns (Fig. 2). In all cell cycle stages the immunostained cells exhibited a pattern of regularly spaced fluorescent dots at the rim of the valve region (Fig. 2a, b). Cells that were close to cell division (i.e. elongated cells) exhibited an additional fluorescent ring along the entire central region of the cell wall (Fig. 2a).

Subsequently, a peptide competition assay (PCA) and immunolocalization with the isolated IgG fraction of the preimmune serum were conducted to investigate the specificity of the peptide antibody. The continuous central ring was absent when isolated IgGs from preimmune serum were used, whereas the dot pattern remained 


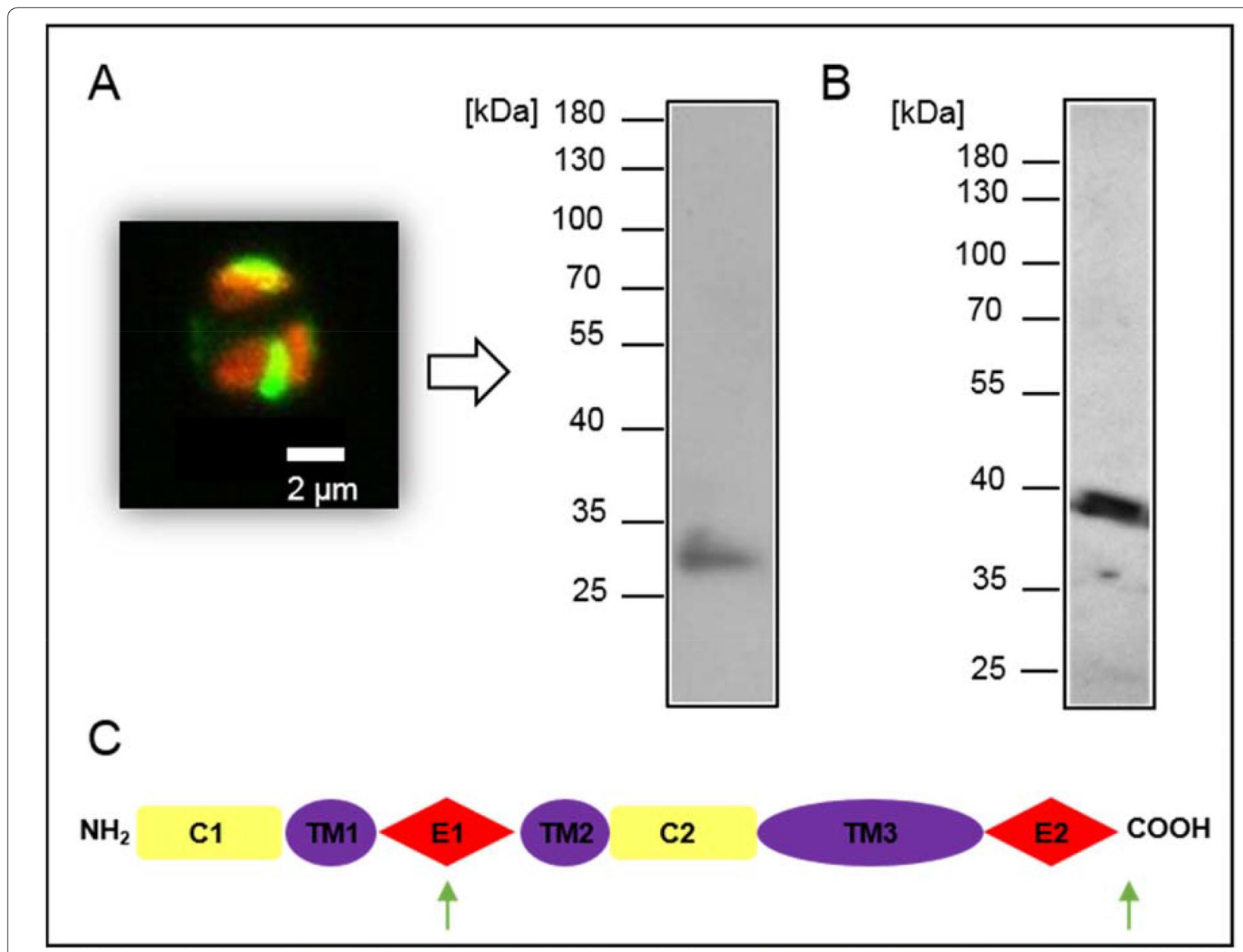

Fig. 1 Localization experiments of chs7305. a Confocal fluorescence microscopy images of T. pseudonana transformants expressing the gene of the C-terminal chitin synthase 7305 fusion protein chs7305-CT-GFP and the corresponding Western blot results against GFP. The micrograph is an overlay of the recorded green channel (excitation: $488 \mathrm{~nm}$, emission: 490-536 nm range) and the red channel (excitation: $633 \mathrm{~nm}$, emission: 647-687 nm range). The green color represents GFP fluorescence, whereas the red color is caused by chloroplast autofluorescence. $\mathbf{b}$ Western blot analysis (against GFP) of T. pseudonana transformants expressing the gene of the chitin synthase 7305 fusion protein chs7305-ED-GFP (159 kDa) with the GFP gene within the extracellular domain E1. c Schematic representation of the domain structure of chs7305 (132 kDa) and the locations of recombinant GFP introduction (green arrows). C: cytosolic domain, E: extracellular domain, TM: transmembrane domain

unchanged (Fig. 2b). This was in agreement with PCA using a 100-times molar excess of peptide vs. antibody, which resulted in absence of the ring while the dots were still visible. These results revealed that only the the ring is a specific signal and represents the location of chs7305.

To investigate the location of chs7305 relative to the biosilica-associated chitin, immunolabelling with antichs7305 antibodies was followed by calcofluor white staining to visualize the chitin. Figure 3 shows that chs7305 and chitin are almost perfectly co-localized as ring-shaped structures in the mid region of the cell wall. As an alternative probe for chitin, CB-GFP was used for the co-localization experiment. CB-GFP is a green fluorescent protein that carries a chitin binding (CB) domain and has previously been used to localize chitin in mollusc shells $[12,24]$. The CB-GFP staining confirmed the results obtained with calcofluor white (not shown).

These results strongly suggest that chs7305 is responsible for the synthesis of the chitin-based ring that is present in the mid-cell region. However, this observation was limited to cell populations that were grown for longer time periods ( $\geq 10$ days). Under these conditions nutrients become limited. During the early phase of growth under abundant nutrient conditions, elongated cells neither showed the presence of chs7305 nor of the chitin-based ring structure (not shown). This observation agrees with the extremely low transcript abundance of chs 7305 and the chitin-binding protein genes $p 150$ and 


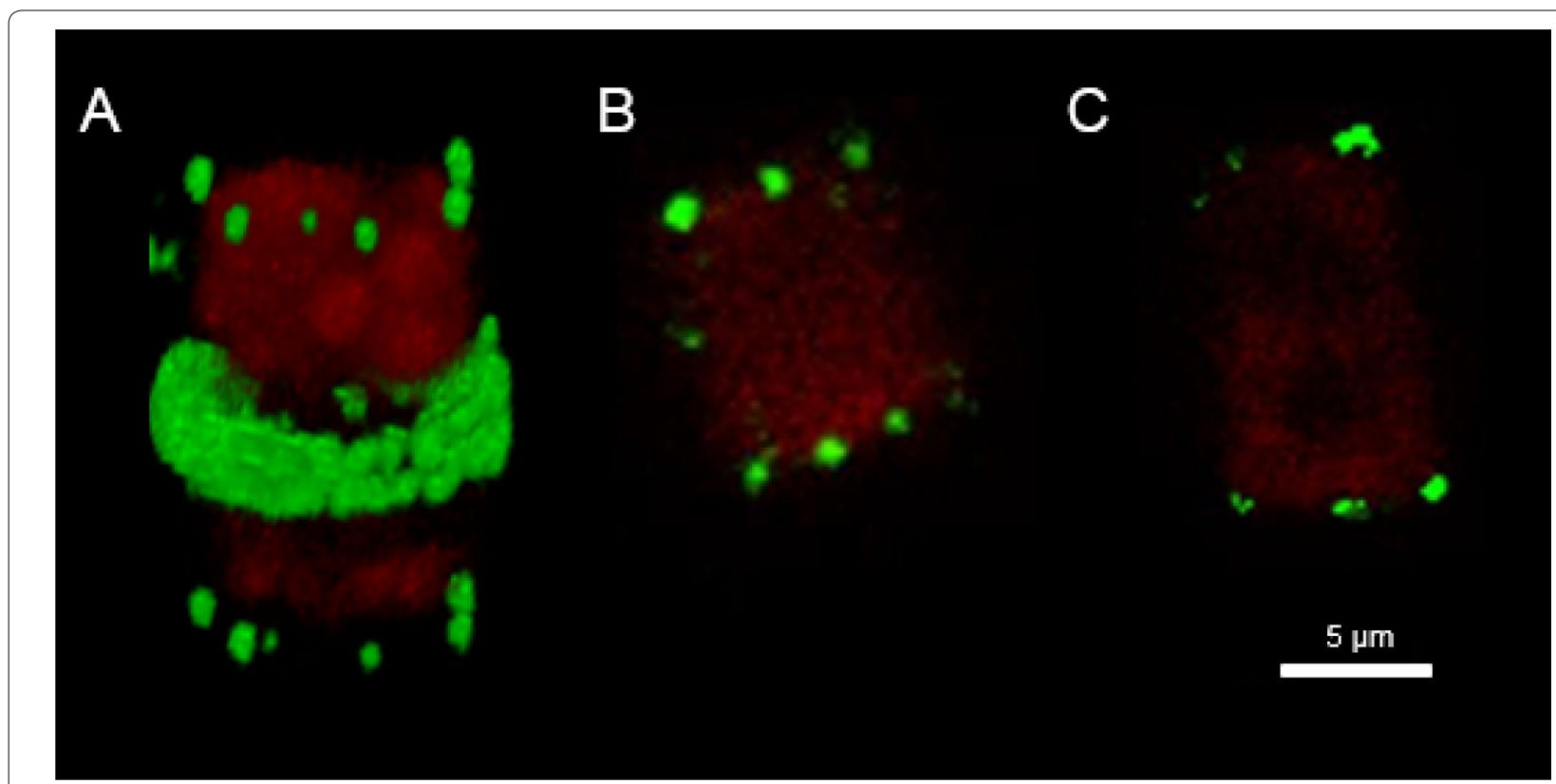

Fig. 2 Images obtained by confocal immunofluorescence microscopy of T. pseudonana. Samples were prepared by immunlocalization of chs 7305 in wild type cells using (a) anti-chs7305. $\mathbf{b}$ lgG fraction isolated from preimmune serum, and $\mathbf{c}$ anti-chs-7305 preincubated with 100-times excess of peptide. Each micrograph is an overlay of two images of the recorded green channel and the red channel (settings according to Fig. 1). The green color represents CFL488 fluorescence (secondary antibody), the red color is caused by chloroplast autofluorescence. The scale bar is valid for images b and $\mathbf{c}$
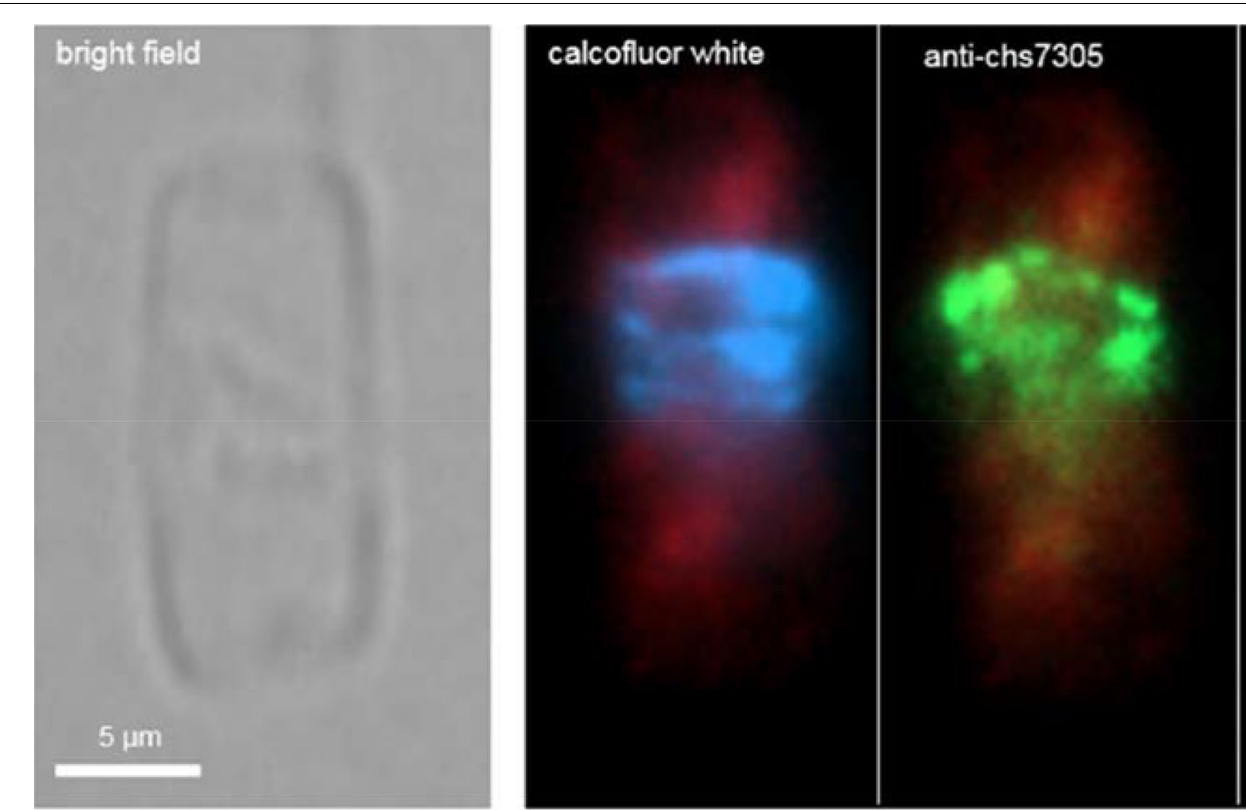

\section{merged}

Fig. 3 Confocal fluorescence microscopy of immunofluorescently labeled cells of T. pseudonana (anti-chs7305). The colocalization of chs7305 with chitin by calcofluor white is shown. Beside the bright field images (left side), fluorescence channels are shown as follows: calcofluor white (excitation: UV, emission: BP 445/50 filter) and anti-chs7305 (excitation: UV, emission: BP 525/50). The fluorescence channels were merged as depicted right. Red fluorescence originates from chloroplast autofluorescence (detected as separate channel) 
p150-like. It indicates that chitin synthesis, in context of the chitin-based ring, is predominately relevant when nutrients become scarce. This suggests that the production of chs7305 and the chitin-based ring could be an adaptation to nutrient limitation. Furthermore, the localization pattern of a girdle band-associated protein, p150, fits well with the localization observed in this study. p150 is highly upregulated under stress conditions such as high copper and low silicon or iron concentrations [25].

To investigate potential functional connections between chs7305, p150, and p150-like their mRNA abundance in dependence on the cell density was compared (Fig. 4). This clearly shows that the three genes were drastically upregulated in the late growth phase. Compared to the exponential growth phase $\left(0.5^{*} 10^{6} \mathrm{cells} / \mathrm{mL}\right)$, chs 7305, p150, and p150-like are 13-, 234-, and 25-times upregulated in the stationary phase $\left(2.0^{*} 10^{6}\right.$ cells $\left./ \mathrm{mL}\right)$.

The occurrence and the localization pattern of chs7305 and chitin also fits well with localization studies previously conducted with $T$. pseudonana and other diatom species [18]. The authors of this study detected chitin in silicic acid-starved cells of several diatom species and interpreted its appearance as an adaptation of frustule formation under changing environmental conditions. This suggests that chitin could be an important component in the adaptation to the reduction of nutrients. The depletion of silicic acid from the growth medium may require stabilizing support for the silica-based cell walls. A chitin-based structure could be able to provide additional strength to the cells walls so that its integrity can be preserved. This stabilization is, in turn, not required during early growth stages where sufficient silicic acid is available to form more stable cells walls. This is supported by transcriptome and proteome analyses which

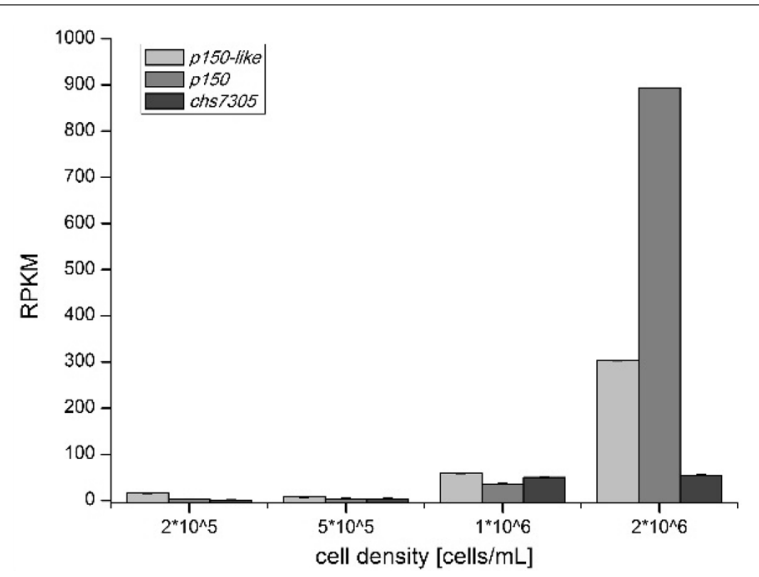

Fig. 4 Transcript abundance of chitin synthase 7305 and the chitin-binding proteins p150 and p150-like. The abundance is given as reads per kilobase per million mapped reads (RPKM) also detected an increased expression of chitin-related genes under different nutrient limitations [26-29] and is in agreement with the observation that chs7305 is detectable in cultures grown for longer time periods, when the nutrient concentration is significantly decreased.

Chitin-based ring structures are also known from other organisms. For instance, budding yeasts produce a primary septum composed of chitin during cell division suggesting an involvement of the chitin synthase in separation of the mother and daughter cell [30,31]. Degradation of the primary septum by a chitinase enables the mother and daughter cell to separate [32]. Chitin-binding proteins, such as p150, could induce the controlled degradation of the observed chitin-based ring. It is known that chitinolytic enzymes such as chitin-active lytic polysaccharide monooxygenases bind to chitin and in some cases produce nicks by an oxidative reaction [33]. Thus, chs7350 and p150 could be part of a regulative machinery that controls cell wall integrity in the girdle band region. This may give an explanation of the observation of elongated cell morphologies in course of the upregulation of p150.

\section{Conclusions}

The investigations on chs7305 from T. pseudonana showed that this chitin synthase is not involved in the formation of chitin fibers, but in the formation of a chitin-based ring at the girdle band region of elongated cells after growth for 10 days or longer. Interestingly, the chitin meshwork found in T. pseudonana was also isolated under similar condition. This indicates that the chitinbased ring might play a role for stabilization of the cell wall. It will be of interest to see, whether similar chitin structures can also be found in other diatoms harboring several potential chitin synthase genes. For experimental elucidation of the function of the chitin-based ring structure, knock-out or knock-down experiments will be necessary.

\footnotetext{
Abbreviations

BSA: bovine serum albumin; CB-GFP: chitin-binding green-fluorescent protein; CT: carboxy terminal; GFP: green-fluorescent protein; lgG: immunglobulin G; kDa: kilo Dalton; LCPA: long chain polyamines; PAGE: polyacrylamide gel electrophoresis; PCA: peptide competition assay; PDMPO: (2-(4-pyridyl)-5-((4(2-dimethylaminoethyl-aminocarbamoyl)methoxy)-phenyl)oxazole); PVDF: polyvinylidene fluoride; RPKM: reads per kilobase per million mapped reads; SDS: sodium dodecyl sulfate; Tris: tris(hydroxymethyl)aminomethane; UV:
} ultraviolet.

\section{Acknowledgements}

The authors thank the Deutsche Forschungsgemeinschaft for financial support through Research Unit 2038 "NANOMEE" (PE 348/31-1 and KR 1853/8-2) The calcination of biosilica by C. Fischer (TU Dresden) is gratefully acknowledged. We would like to thank Ingrid Weiss (University Stuttgart) for kindly 
providing the CB-GFP plasmid, and Beate Brankatschk (TU Dresden) for technical support.

\section{Authors' contributions}

MW planned and performed the experiments and wrote the manuscript. NP was involved in the planning of some of the experiments and in writing the manuscript. NK contributed to the writing of the manuscript. K-HvP designed and supervised the study and contributed to the writing of the manuscript. All authors have read and approved the manuscript.

\section{Funding}

This research was funded by the Deutsche Forschungsgemeinschaft (PE 348/31-1 and KR 1853/8-2). The funding body played no roles in the design of the study and collection, analysis, and interpretation of data and in writing the manuscript.

\section{Availability of data and materials}

All data generated or analyzed during this study are included in the article. Data sets from individual experiments can be obtained from the corresponding authors upon reasonable request.

\section{Competing interests}

The authors declare that they have no competing interests.

\begin{abstract}
Author details
${ }^{1}$ General Biochemistry, Technical University of Dresden, 01062 Dresden, Germany. ${ }^{2}$ B CUBE - Center for Molecular Bioengineering, Technical University of Dresden, Tatzberg 41, 01307 Dresden, Germany. ${ }^{3}$ Cluster of Excellence Physics of Life, TU Dresden, 01062 Dresden, Germany. ${ }^{4}$ Faculty of Chemistry and Food Chemistry, TU Dresden, 01062 Dresden, Germany.
\end{abstract}

Received: 14 May 2020 Accepted: 22 July 2020

Published online: 26 August 2020

\section{References}

1. Round FE, Crawford RM, Mann DG. The diatoms: biology and morphology of the genera. Cambridge: Cambridge University Press; 1990.

2. Pickett-Heaps J, Schmid A, Edgar L. The cell biology of diatom valve formation. In: Round FE, Chapman DJ, editors. Progress in phycological research, vol. 7. Bristol: Biopress Ltd; 1990. p. 1-168.

3. Kröger N, Poulsen N. Diatoms-from cell wall biogenesis to nanotechnology. Annu Rev Genet. 2008;42:83-107.

4. Hildebrand M, Lerch SJL, Shrestha RP. Understanding diatom cell wall silicification—moving forward. Front Mar Sci. 2018:2018(5):125.

5. Brunner E, Richthammer E, Ehrlich H, Paasch S, Simon P, Ueberlein S, van Pée K-H. Chitin-based organic networks: an integral part of cell wall biosilica in the diatom Thalassiosira pseudonana. Angew Chem Int Ed. 2009:48:9724-7.

6. Scheffel A, Poulsen N, Shian S, Kröger N. Nanopatterned protein microrings from a diatom that direct silica morphogenesis. Proc Natl Acad Sci USA. 2011:108:3175-80

7. Kotzsch A, Pawolski D, Milentyev A, Shevchenko A, Scheffel A, Poulsen N, Shevchenko A, Kröger N. Biochemical composition and assembly of biosilica-associated insoluble organic matrices from the diatom Thalassiosira pseudonana. J Biol Chem. 2016;291:4982-97.

8. Lowenstam HA, Weiner S. On biomineralization. New York: Oxford University Press; 1989.

9. Ehrlich $\mathrm{H}$. Chitin and collagen as universal and alternative templates in biomineralization. Int Geol Rev. 2010:52:661-99.

10. Suzuki M, Sakuda S, Nagasawa H. Identification of chitin in the prismatic layer of the shell and a chitin synthase gene from the Japanese pearl oyster, Pinctada fucata. Biosci Biotechnol Biochem. 2007;71:1735-44.

11. Weiner S, Lowenstam H. Organization of extracellularly mineralized tissues: a comparative study of biological crystal growth. Crit Rev Chem. 1986;20:365-408.

12. Weiss IM, Schönitzer V, Eichner N, Sumper M. The chitin synthase involved in marine bivalve mollusk shell formation contains a myosin domain. FEBS Lett. 2006;580:1846-52.
13. Mann S. Biomineralization: principles and concepts in bioinorganic materials chemistry. Oxford: Oxford University Press; 2001.

14. Suzuki M, Saruwatari K, Kogure T, Yamamoto Y, Nishimura T, Kato T, Nagasawa H. An acidic matrix protein, Pif, is a key macromolecule for nacre formation. Science. 2009;325:1388-90.

15. Herth $W$. The site of beta-chitin fibril formation in centric diatoms. I. Pores and fibril formation. J Ultrastruct Res. 1979:68:16-27.

16. Herth W, Mulisch M, Zugenmaier P. Chitin in nature and technology. Boston: Springer; 1986. p. 107-20.

17. McLachlan J, McInnes AG, Falk M. Studies on the chitan (chitin: poly-Nacetylglucosamine) fibers of the diatom Thalassiosira fluviatilis hustedt: I production and isolation of chitan fibers. Can J Bot. 1965;43:707-13.

18. Durkin CA, MockT, Armbrust EV. Chitin in diatoms and its association with the cell wall. Eukaryot Cell. 2009;8:1038-50.

19. Armbrust EV, Berges JA, Bowler C, Green BR, Martinez D, Putnam NH, Zhou S, Allen AE, Apt KE, Bechner M, Brzezinski MA, Chaal BK, Chiovitti A, Davis AK, Demarest MS, Detter JC, Glavina T, Rokhsar DS. The genome of the diatom Thalassiosira pseudonana: ecology, evolution, and metabolism. Science. 2004;2004(306):79-86.

20. Harrison PJ, Waters RE, Taylor FJR. A broad spectrum artificial sea water medium for coastal and open ocean phytoplankton. J Phycol. 1980;16:28-35.

21. Poulsen N, Chesley PM, Kröger N. Molecular genetic manipulation of the diatom Thalassiosira pseudonana (Bacillariophyceae). J Phycol. 2006;42:1059-65.

22. Hedrich R, Machill S, Brunner E. Biomineralization in diatoms-phosphorylated saccharides are part of Stephanopyxis turris biosilica. Carbohydr Res. 2013;365:52-60.

23. Fischer C, Adam M, Mueller AC, Sperling E, Wustmann M, van Pée K-H, Kaskel S, Brunner E. Gold nanoparticle-decorated diatom biosilica: a favorable catalyst for the oxidation of D-glucose. ACS Omega. 2016;1:1253-61.

24. Nudelman F, Chen HH, Goldberg HA, Weiner S, Addadi L. Lessons from biomineralization: comparing the growth strategies of mollusc shell prismatic and nacreous layers in Atrina rigida. Faraday Discuss. 2007:136:9-25.

25. Davis AK, Hildebrand M, Palenik B. Characterization of a modular, cellsurface protein and identification of a new gene family in the diatom Thalassiosira pseudonana. J Phycol. 2005:41:577-89.

26. Dyhrman ST, Jenkins BD, Rynearson TA, Saito MA, Mercier ML, Alexander $\mathrm{H}$, Whitney LP, Drzewianowski A, Bulygin VV, Bertrand EM, Wu Z, BenitezNelson C, Heithoff A. The transcriptome and proteome of the diatom Thalassiosira pseudonana reveal a diverse phosphorus stress response. PLOS ONE. 2012;7:e33768.

27. Nunn BL, Faux JF, Hippmann AA, Maldonado MT, Harvey HR, Goodlett DR, Boyd PW, Strzepek RF. Diatom proteomics reveals unique acclimation strategies to mitigate Fe limitation. PLoS ONE. 2013;8:e75653.

28. Du C, Liang J-R, Chen DD, Xu B, Zhuo W-H, Gao Y-H, Chen C-P, Bowler C, Zhang W. ITRAQ-Based proteomic analysis of the metabolism mechanism associated with silicon response in the marine diatom Thalassiosira pseudonana. J Proteome Res. 2014;13:720-34.

29. Mock T, Samanta MP, Iverson V, Berthiaume C, Robison M, Holtermann K, Durkin C, BonDurant SS, Richmond K, Rodesch M, Kallas T, Huttlin EL, Cerrina F, Sussman MR, Armbrust EV. Whole-genome expression profiling of the marine diatom Thalassiosira pseudonana identifies genes involved in silicon bioprocesses. Proc Natl Acad Sci USA. 2008;105:1579-84.

30. Cabib E, Arroyo J. How carbohydrates sculpt cells: chemical control of morphogenesis in the yeast cell wall. Nat Rev Microbiol. 2013;11:648-55.

31. Soll DR, Mitchel LH. Filament ring formation in the dimorphic yeast Candida albicans. J Cell Biol. 1983;96:486-93.

32. Kuranda MJ, Robbins PW. Chitinase is required for cell separation during growth of Saccharomyces cerevisiae. J Biol Chem. 1991;266:19758-67.

33. Aachmann FL, Sorlie M, Skjak-Braek G, Eijsink VGH, Vaaje-Kolstad G. NMR structure of a lytic polysaccharide monooxygenase provides insight into copper binding, protein dynamics, and substrate interactions. Proc Natl Acad Sci USA. 2012;109:18779-84.

\section{Publisher's Note}

Springer Nature remains neutral with regard to jurisdictional claims in published maps and institutional affiliations. 